\title{
Sustainable Supply Chain Management in Iranian Manufacturing Companies
}

\author{
Maryam Azizsafaei and Deneise Dadd \\ Published Version of Record deposited by Coventry University's Repository \\ Original citation \& hyperlink: \\ Azizsafaei, Maryam, and Deneise Dadd. "Sustainable Supply Chain Management in Iranian \\ Manufacturing Companies." International Journal of Strategic Engineering (IJoSE) 3.2 (2020): \\ 37-58. \\ http://dx.doi.org/10.4018/IJoSE.2020070103
}

$\begin{array}{ll}\text { DOI } & 10.4018 / \text { IJoSE.2020070103 } \\ \text { ISSN } & 2572-4959\end{array}$

Publisher: IGI Global

Copyright ( $) 2020$ IGI Global. This article is made available from an institutional repository in line with the publisher's self-archiving policy. Further distribution is not permitted without the copyright holder's permission.

A copy can be downloaded for personal non-commercial research or study, without prior permission or charge. This item cannot be reproduced or quoted extensively from without first obtaining permission in writing from the copyright holder(s). The content must not be changed in any way or sold commercially in any format or medium without the formal permission of the copyright holders. 


\title{
Sustainable Supply Chain Management in Iranian Manufacturing Companies
}

\author{
Maryam Azizsafaei, University of Northampton, Northampton, United Kingdom \\ Deneise Dadd, Coventry University, Coventry, United Kingdom \\ (iD) https://orcid.org/0000-0002-0083-852X
}

\begin{abstract}
Despite the considerable concentration on sustainable supply chain management (SSCM) among manufacturing organizations, Iranian manufacturing companies are still in the initial stage. Due to significant development in manufacturing industries in Iran, environmental concerns have become the highest concerns for stakeholders. SSCM practices have a straightforward linkage with environmental performance. Consequently, this question was raised that what are the impacts of adopting SSCM practices on environmental performance (EP) in Iranian manufacturing companies? According to the results of this study, the following outcomes have obtained: there is a positive relationship between sustainable purchasing and sustainable logistics and internal environmental management (IEM). On the contrary, sustainable production and sustainable design have not a significant relationship with IEM. In addition, the findings indicate the positive and significant effect of SSCM practices on EP.
\end{abstract}

\section{KEYWORDS}

Environmental Performance (EP), Internal Environmental Management (IEM), Iranian Manufacturing, Manufacturing Organisations, Multiple Regressions Model, Sustainable Supply Chain Management (SSCM)

\section{INTRODUCTION}

This section attempts to provide an outline of the background, scope, research question and objectives, research significance, and research structure in this study.

\subsection{Research Background}

One of the most significant leverages and competitive advantage of the current business climate is appropriate management of supply chains (Bratic, 2011; Carter and Ellram, 2003). The general consciousness and knowledge regarding environmental aspects along with concentration on supply chain management are growing (Giunipero et al., 2008). Intensive pressures are being exerted from regulatory bodies regarding clearance of environmental and ethical performance in different organisations. In addition, increasing expectation of stakeholders along with pressures from institutions play a significant role in shifting from the traditional supply chain management (SCM) to Sustainable Supply Chain Management (SSCM) (Kumar et al., 2014a; Lozano, 2008; Vezzoli et al., 2012). Due to various processes and operations in SCM with direct impacts on the environmental aspect, the continual measurement of environmental performance is essential (Handfield et al., 2005).

SSCM integrates SCM and sustainable development (SD) support companies to decrease their current SCM costs and attain a considerable competitive superiority (Seuring and Müller, 2008). In 
the last decade, significant numbers of literature and industries indicate particular interest regarding two contents: SSCM and Green Supply Chain Management (GSCM). This particular focus relies on the fact that they are optimistic about minimising adverse effects on the environment by adopting SSCM practices (Mudgal et al., 2009; Lozano et al., 2015).

However, Zhu et al. (2013) debate that there is a lack of comprehensive literature by focusing on the causal relationship between SSCM constructs and their equivalent performance outcomes. This inadequacy is more significant in emerging countries, such as Iran, compared to developed countries, such as the UK (Jayaram and Avittathur, 2015).

According to latest ranking of the World Economic Forum (2018) based on the Inclusive Development Index (IDI), Iran ranks $27^{\text {th }}$ among the 74 emerging countries, which illustrates a $0.92 \%$ decrease between 2012 and 2016. The three main pillars that were measured in this assessment include growth and development, inclusion, and intergenerational equity and sustainability. Each pillar is evaluated using the key performance indicators such as GDP per capita growth, labour proactivity growth, net income trend, poverty trend, carbon intensity trend, etc. Lithuania, Hungary, Azerbaijan, Latvia, Poland, Panama, Croatia, Uruguay, Chile, and Romania are the top 10th emerging countries in this list.

Consequently, this study attempts to identify the potential impacts of SSCM practices on environmental performance and bridge the knowledge gap in the recent literature. This study particularly concentrated on manufacturing organisations in Iran. Manufacturing companies, as the considerable consumers of the energy and other resources, can have extensive impacts on environmental performance. Both global and domestic areas can be affected by the consequences of this considerable resource consumption and its corresponding environmental destruction by manufacturing sections (Kuik et al., 2011).

\subsection{Research Scope}

The main aim of this paper is evaluating the implication of adopting SSCM practices on environmental performance (EP) outcomes. In addition, Internal Environmental Management (IEM) as one of the significant approaches for successful SSCM implementation is evaluated. In terms of IEM, this research attempts to realise its impact on four specific SSCM practices. These practices include sustainable purchasing (SPr), sustainable design (SD), sustainable logistics (SL), and sustainable production (SP). Furthermore, the cause-and-effect relationship between SSCM practices and EP is investigated.

Moreover, as mentioned before the geographical location for collecting data in this research is in Iran, with a focus on manufacturing companies. The selected organisations in this study include four petrochemical companies, one agriculture company, and one steel manufacturing company.

\subsection{Research Questions and Objectives}

Considering the identified research gaps in evaluating SSCM adoption and its impacts on environmental performance, the major research question of this study is as follows:

RQ1: What are the impacts of adopting Sustainable Supply Chain Management practices on environmental performance in Iranian manufacturing companies?

Accordingly, the major aim of this research is generating a conceptual framework for realising the linkage between SSCM adoption and environmental performance. This research looks to answer the proposed research question by meeting these objectives:

- Realise the essential Sustainable Supply Chain Management practices in Iranian manufacturing organisations. 
- Investigate the Internal Environmental Management effects on Sustainable Supply Chain Management practice.

- Evaluate Sustainable Supply Chain Management practice's impacts on Environmental Performance.

- Conceptualise and test the Internal Environmental Management- Sustainable Supply Chain Management practices- Environmental Performance model.

\subsection{Research Significance}

In this section, both academic and practical significance are represented.

\subsubsection{Academic Significance}

Although initial studies evaluated the linkage between the adoptions of SSCM practices and EP (Lee et al., 2012; Zhu and Sarkis, 2004), contemporary research interrogated the previous studies about this relationship (Walker and Jones, 2012). Due to existing doubts associated with the current knowledge, further research is required. This research was attempted generating information that minimises the gaps and uncertainties in the current literature.

\subsubsection{Practical Significance}

This research provided a beneficial vision for both managers and regulatory bodies who try to implement the SSCM practices and aim to improve the SSCM agenda, respectively. Producers and manufacturing companies can achieve managerial vision regarding how to improve environmental outcomes along with their supply chain processes by adopting SSCM practice in their organisations. Hence, legislators can take a significant understanding of how to enhance the intention of SSCM implementation in manufacturing companies.

On the other hand, SSCM content, particularly in EP dimension, is not an explored research agenda in the Iranian manufacturing companies (Feizpour and Mehrjardi, 2014). Accordingly, this research is completely practical for Iranian manufacturing companies as the initial step of evaluating impacts of SSCM practices on EP. Based on this research, they also can recognise the critical role of IEM approach on more successful SSCM implementation in their firms.

\subsection{Research Structure}

This study is structured into five different section. The first section (Introduction) provided an outline of this study. The research background, research scope, research objectives, and question are the main sections of the introduction. In addition, research significance and structure of this study were reviewed.

In the second section (Literature Review), according to related literature, theoretical background and key research clusters are provided. These determine the relevant SSCM practices that supports the conceptual framework (IEM-SSCM practices-EP) generated. This framework is used to efficiently answer the main research question. Also, in this section, the conceptualisation of the theoretical model and the reasons for the addition of the research constructs into the model are argued. Moreover, hypotheses regarding two different models are proposed. The first model is used to evaluate the relationship between IEM adoption and SSCM practice. The second model is used to investigate the linkage between SSCM practice and EP outcomes. The final part of section 2 presents the research model.

The research methodology is outlined in Section 3 and includes the philosophy, approach, strategy, and research design. Furthermore, the data collection and analysis methods are presented in this section. Analysis and Results in section 4 presents the data analysis method of multiple regressions and its descriptive findings. This section illustrates the structure of data preparation, data quality assessment steps and finally measurement assessment model. Through the critical discussions, based on the results, causal relationships between IEM and SSCM practices and SSCM adoption and EP 
International Journal of Strategic Engineering

Volume $3 \cdot$ Issue 2 • July-December 2020

outcomes is specified. Section 5 (Conclusions) revisits the research objectives, answers the research question, and the outcomes are summarised.

\section{LITERATURE REVIEW}

The major goal of this section is to evaluate the literature about SSCM to determine the background of the theoretical concepts related to the research aspects. Accordingly, this section analyses and expands the core research clusters for answering the research question. In addition, based on the research objectives, the main concentration of this research is identifying the conceptual framework of SSCM practices and their impact on EP.

\subsection{Supply Chain Moving Toward Sustainability}

Business activity steadily began to concentrate on environmental aspects from the 2000s simultaneously with revolutions in quality and supply chain (Srivastava, 2007). Meanwhile, because of logic control in automation, machinery, and assembly production lines, the production volume considerably increased (Tu et al., 2001; Nahm and Vonderembse, 2002).

However, increasing production exerted direct effects on environmental issues such as pollution, different types of waste, and emissions (Vonderembse et al., 1997). Subsequently, as a result of employing the traditional supply chain in the production process, diverse adverse environmental consequences occurred, such as emission and global warming (Sarkis, 2006). Due to various environmental considerations, regulatory bodies and business companies attempted to employ approaches that make a balance between economic and environmental performance (Nahm and Vonderembse, 2002). Moreover, in the 1990s, due to the high level of competition (Skinner, 1985) and high customers' expectations, most of the industries and businesses employed pull system instead of push system in their supply chain processes. These expectations include quality, differentiation, accessibility and, environmentally friendly merchandise and services (Carter and Easton, 2011). The existing pressures and expectations generated the infrastructure for shifting of traditional SCM to SSCM (Moore and Babu, 2008).

\subsection{Sustainable Supply Chain Management (SSCM)}

In the last twenty years, various companies attempt to utilise the sustainability context toward their decisions-making about different actions (Seuring and Gold, 2013). Dyllick and Hockerts (2002) state that SSCM is established through the combination of two fundamental principles: SD and SCM. Hall and Matos (2010) debate that, as a result of concentrating strategic value of sustainability in line with the supply chain, the SSCM context emerged. They do believe that considerable drivers of SSCM are increasing performance's durability in the various organisation as well as focusing on sustainability importance in business efficiency. SSCM was identified as the system for managing three important flows; material, money, and information throughout the supply chain processes while considering dimensions of SD (Seuring and Muller 2008, p.1700). Seuring and Muller (2008) also argue that sustainable development dimensions were specified as crucial drivers and expectations of stakeholders.

Some significant aspects are not mentioned in the sustainability definition. These aspects include risk management, strategy, culture, and transparency (Carter and Rogers, 2008). As presented in the following paragraphs, there are relationships between these aspects and essential triple bottom line in sustainability framework.

Firms should realise and specify the various risks concerning SSCM practices and establish the appropriate risk management system in their organisation for predicting and overcoming these risks (Carter and Rogers, 2008, p.366). According to Carter and Rogers (2008), transparency can consider as a significant driver for establishing fast pace communication among different corporates and their stakeholders. It was perceived that performing with transparency regarding sustainability dimensions is more cost-effective and straightforward for a company in the long-term. Organisations, in order to 
employ the transparency principles, through a proactive attitude, should consider their stakeholder's requirements and report their progress to them.

In terms of the strategy aspect in the sustainability framework, Carter and Rogers (2008) believe that sustainability challenges and initiatives should consider and manage the corporate strategy in different organisations. Simultaneously, they stated that expanding the culture to foster innovation beside the economic concerns are essential to adopting a sustainability approach in organisations.

Subsequently, Carter and Rogers (2008, p.368) based on mentioned aspects and the core triple bottom line of sustainability defined the SSCM as strategic. They argue this strategy is essential for achieving the organisation's goals in the whole dimensions of social, environmental, and economic.

Teuteberg and Wittstruck (2010) by adopting Carter and Rogers (2008) and Elkington (2004) studies generated the 'House of SSCM.' The triple bottom line was the main principle for building the SSCM house. They stated that sustainability's dimensions were fundamental elements for sustaining balance in the SSCM house. 'Risk and compliance management' is considered as the foundation of this building. In addition, 'Laws, Standards, and Regulations' are another initial stage regarding SSCM that form the foundation of SSCM house. Addressing maintaining the long-term profits and advantages in different organisations, considering the environmental and market risks, are crucial in this model.

\subsection{SSCM in Iranian Manufacturing Companies}

Due to implementation of SSCM practices in Iranian manufacturing companies, they have obtained considerable improvement in their environmental performance. However, they are in the initial phase of SSCM implementation and require further progress comparing to industries in developed countries (Zhu and Sarkis, 2007). Iran as an emerging market economy has enormous potential for greater expansion (Feizpour and Mehrjardi, 2014). However, this fast pace growth had explicit impacts on its environmental aspects, such as enhancing emission and pollution. These environmental damages are considered a strategic problem for the Iranian government. Subsequently, in order to minimise the negative impacts of industries' actions on the environmental dimension, the Iranian government was declared diverse regulations (Tan et al., 2014). Concerning motivating Iranian manufacturing organisations to take voluntary responsibility in environmental safety and protection, the government established various green motivations. Proactive and preventive actions are recent activities by the Iranian government to mitigate the environmental damages at initial stages (Soltani et al., 2015). Evaluation and selection of suppliers based on environmental certification is one of the proactive actions that the government has undertaken in Iranian manufacturing companies. They have also considered special rewards for manufacturing companies that have implemented sustainable production. This is done by employing activities such as remanufacturing, recycling, and reusing, which can support organisations to reduce resource consumption and different types of wasting (Zhu et al. 2008c). The most SSCM practices that were placed in Iranian government priority include sustainable purchasing, sustainable production, sustainable design, sustainable distribution (Govidan et al, 2014a).

This study has described the four practices according to SSCM framework and their developing importance for Iranian manufacturing companies. The four main SSCM initiatives include sustainable production, sustainable design, sustainable logistics, sustainable purchasing. These initiatives can cover the more significant activities inside and outside of organisations across the SSCM (Zhu et al., 2005).

These groups of SSCM initiatives contribute to the manufacturing organisation to help minimise the negative impacts on the environmental aspect across their products' life cycle. The cycle often starts by designing processes and consist of functions from sourcing to the disposal (Zsidisin and Siferd, 2001).

The hypotheses in this research are proposed based on the contingency prospect. In addition, these hypotheses adopted by various scholars for generating cause and effect linkage (Carter and Jennings, 2004). The contingency prospect indicates that expected hypotheses are right or wrong under every circumstance and assist this study to reject or accept the hypotheses (Layder, 1988). 
International Journal of Strategic Engineering

Volume $3 \cdot$ Issue 2 • July-December 2020

\subsection{Hypothesis Development}

The main objective of this section is indicating hypotheses by theoretical foundation regarding the linkage between IEM- SSCM practices- EP with the experimental confirmation within the interrelated literature. The hypotheses in this research are proposed based on the contingency prospect. In addition, these hypotheses adopted by various scholars for generating cause and effect linkage (Green et al., 2012b; Carter and Jennings, 2004). The contingency prospect indicates that expected hypotheses are right or wrong under every circumstance and assist this study to reject or accept the hypotheses (Layder, 1988).

\subsection{Internal Environmental Management (IEM) and SSCM practices}

Initially, the IEM incorporate appreciable practices that includes engagement and commitment of managers in the different levels; implementation of total quality environmental management (TQEM); achieving ISO 14001 certification; evaluating environmental conformity by adopting auditing plan (Green et al., 2012a; Zhu et al., 2008a; Seuring and Muller, 2008).

The IEM practices are supposed to contain a straightforward relationship with the successful adoption of SPr, SP, SD and SL (Hsu et al., 2013; Hu and Hsu, 2010). Furthermore, the pieces of evidence within literature represent the linkage between implementation of the SPr, SP, SD and SL practices and the IEM (Sarkis et al., 2010; Hsu et al., 2013; Hu and Hsu, 2010).

The following hypotheses are proposed based on the previous discussion:

- H1a: Internal Environment Management has positive impacts on Sustainable Purchasing

- H1b: Internal Environment Management has positive impacts Sustainable Production

- H1c: Internal Environment Management has positive impacts on Sustainable Logistics

- H1d: Internal Environment Management has positive impacts on Sustainable Design

\subsection{SSCM Practices and EP}

As mentioned before, SSCM practices were employed due to requirements from the regulatory organisations and other drivers, and the adoption of SSCM practices was predicted to have impacts on EP (Green et al., 2012a). In essence, due to environmentally friendly features of SSCM practices, their adoption can minimise materials and energy usage, total wastes types, air pollution, and emissions that whole of these constructs were used for measurement of EP (Seuring and Muller, 2008). Therefore, the following hypotheses are proposed:

- H2a: Sustainable Purchasing has positive impacts on Environmental Performance

- H2b: Sustainable Production has positive impacts on Environmental Performance

- H2c: Sustainable Logistics has positive impacts on Environmental Performance

- H2d: Sustainable Design has positive impacts on Environmental Performance

Figure 1 illustrates the final research model in this research.

\section{RESEARCH METHODOLOGY}

The vast majority of outstanding authors such as Saunders et al. (2009) and Bryman and Bell (2015) mentioned the following philosophical research in their studies particularly in business research: positivism, realism, interpretivism, and pragmatism. The two essential research philosophies that is adopted in SCM and operation management studies are positivism and interpretivism (Golicic and Davis, 2012). Positivism is defined as a philosophical view that verifies information through a rational approach (Saunders et al., 2009). This research has adopted the positivist philosophy to 


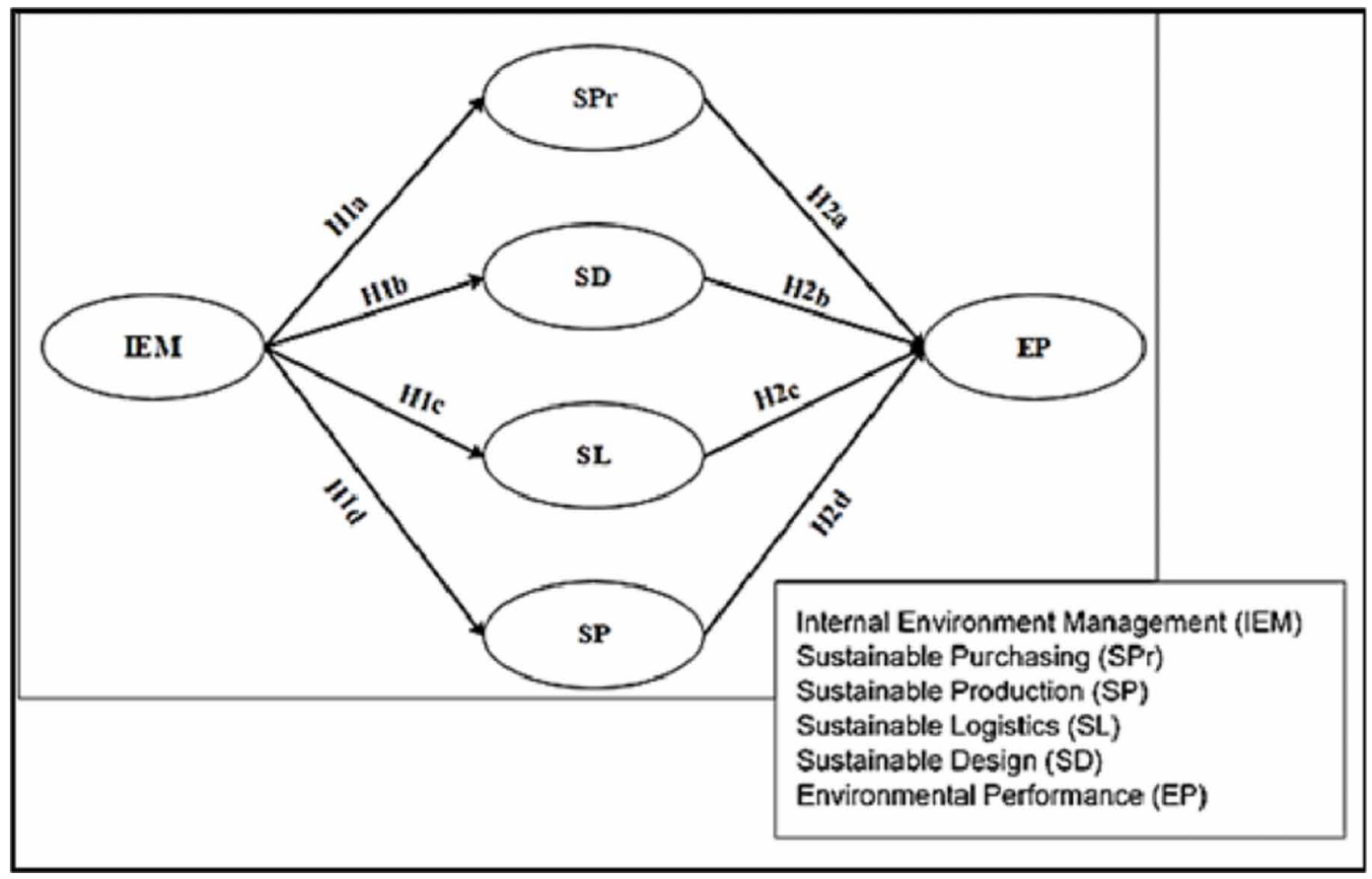

develop the research model according to associated theories. This paradigm supports this study to not only develop theory via utilising causalities but also testing the adopted theory through empirical investigation (Saunders et al., 2009). Moreover, statistical techniques are important and applicable in positivist research. The reason lies in the fact that this philosophy follows the structured framework in the study to show the reality of the objective (Carson et al., 2001). In contrast, Interpretivism has not followed a rigid structural technique and employed a customised and flexible structure in the study (Carson et al., 2001).

The common research approaches that are broadly used in business researches are categorised into three major groups. These groups include deductive, inductive or abductive research approaches (Bryman, 2001). Due to the explanatory approach in this study, the deductive method was considered as the most appropriate research approach for testing theories and developing a conceptual framework (Bryman, 2001). The deductive researches approach is in line with positivism philosophy. The reason lies in the fact that the most priority of the deductive research is mostly on cause and effect connection. While in inductive research the main purpose is finding phenomena by comprehensive analysis (Saunders et al., 2009). Furthermore, commonly quantitative researches in the supply chain areas adopted the deductive approach regarding testing their theories (Chicksand et al., 2012).

In line with the selected research methodology in this study, the quantitative method was adopted for testing current theories and knowledge. This method is deemed adequate because it has the potential for accomplishing appropriate investigation to respond to the main research question (Bryman and Bell, 2015).

The role of the research strategy is fundamental through various social researches. It is considered as a facilitator for answering the research question (Saunders et al., 2009). In this study, the survey approach was employed as a research strategy. It supports this research to comply with its principal objectives and respond to the research question. Since the survey strategy is influenced by the logic of the deductive approach, it employs the empirical investigation for testing current knowledge 
(Bryman and Bell, 2015). In addition, the survey strategy is affected by the main aim of the research, which as mentioned before is explanatory. Generally, explanatory research has employed surveys or experiments in the research (Bryman, 2001). The survey is considered as the most frequently adopted research strategy in SCM area, which is followed by case studies strategy (Mentzer and Kahn, 1995; Giunipero et al., 2008; Chicksand et al. 2012). It is clearly seen that the selection of research strategy type is accordingly affected by the types of research question(s) (Bryman, 2001).

Bryman and Bell (2015) do believe that making a decision about the data collection method is widely related to the availability of resources such as time and money. In addition, the proficiency of the researchers also played a significant role in the choice of data collection techniques. Accordingly, the survey questionnaire is considered as an appropriate method because it is a quick, explicit, inexpensive, and adequate instrument for achieving the necessary information across research questions (Forza, 2002). The self-administered and interviewer-administered questionnaires are two major groups of business research. The self-administered questionnaires include delivery-collection, Internet-mediated, and postal questionnaires. In this type of questionnaires, the researchers do not need to be present for collecting data and the questionnaire will be sent and received by email or web-based service. The interviewer-administered questionnaires are organised interviews that researchers are required to be present for data collection (Saunders et al., 2009). An Internet-mediated self-administered questionnaire is adopted in this study for testing and explaining the causal linkage between different constructs in this research. However, due to poor internet connection in some target cities in Iran and other security issues in different companies, the questionnaires were sent and received by email.

The survey questionnaire in this study contains three main parts. Section A is collecting data about the participants and their organisations. Section B and C adopted the five points Likert-type scale. The preliminary research for this measurement scale in SSCM practices was developed by Zhu and Sarkis (2004). Subsequently, Zhu et al. (2008a) add the performance outcome into this measurement. The existing status of SSCM practices in the different Iranian manufacturing firms is evaluated in section B. The predicted environmental performance outcomes are analysed by section $\mathrm{C}$ in this questionnaire. Most participants in this survey are manager level in SCM processes. Choosing the manager level to assist in this study because they could provide more precise and accurate results.

This study employed the measurement scale of Zhu et al. (2008a) in developing the survey. In addition, measurement scales by other authors in different journals such as Green et al. (2012a); Lee et al. (2012); Hollos et al. (2012); Zhu et al. (2010); Zhu et al. (2013) was considered for this research. It should be mentioned that, most of the mentioned researchers adopted this measurement scale particularly for manufacturing sectors (Zhu et al., 2013). As the data sources of this study are Iranian manufacturing companies, the survey questionnaire was generated in two versions of English and Persian language. Therefore, the Persian questionnaires are translated into English after receiving from participants. The multiple regression analysis methods were selected as the main data analysis method in this research.

In this study, the multiple regression method first requires considering SSCM practices as dependent variables and IEM as the independent variable. Then, in the next phase, the SSCM practices is considered as the independent variable and environmental performance as the dependent variable. It should be mentioned that the analysis is performed in the individual company's level and then is aggregated for the whole of cases. Structural equation modelling (SEM) and multiple regression are the most appropriate data analyse methods for investigating multiple relationships between different variables (Hair et al., 2010). Due to the multiple regression advantages and limitations through different methods, the multiple regression analysis methods were selected as the main data analysis method in this research. 


\section{ANALYSIS AND RESULTS}

\subsection{Data Preparation}

As mentioned in the previous section, this research adopted the Internet-mediated self-administrated survey for collecting data. After collecting the whole questionnaire and translating them from Persian to English, data was transferred manually to an Excel file. The data was categorised by company code, and the variables also coded based on the research model. Table 1 illustrates different codes for measurement items in this study.

\section{Table 1. Variable codes}

\begin{tabular}{|c|l|}
\hline Variables & Code \\
\hline Internal Environmental Management & IEM \\
\hline Sustainable Purchasing & SPr \\
\hline Sustainable Design & SD \\
\hline Sustainable Production & SP \\
\hline Sustainable Logistics & SL \\
\hline Environmental Performance & EP \\
\hline
\end{tabular}

Two critical aspects should be considered when evaluating the suitability of the data collection method. These aspects include missing data and distribution of data (Field, 2009). The Internetmediated self-administrated survey was not an effective survey method for mitigating the risk of missing data. Consequently, the questionnaires with missing data were removed from this research.

\subsection{Data Distribution}

The next major issue is evaluating the data distribution to ensure collected data has normal statistical distribution. Accordingly, the data were transferred from the Excel sheet into an SPSS data file. In this research, the IBM SPSS version 25.00 was employed. The average of different question's answers for all samples were computed in SPSS file regrading to summarize the research constructs.

For instance, some of the average formulations for research constructs are represented in the following formula:

$$
\begin{aligned}
& \text { Mean }(\text { IEM } 1+\text { IEM } 2+\text { IEM3 + IEM4 + IEM } 5+\text { IEM6 + IEM7 })=\text { IEM } \\
& \text { Mean }(\text { SP1 + SP2 + SP3 + SP4 + SP5 + SP6 })=\text { SP }
\end{aligned}
$$

The average of different variables supports this research to analyse the data distribution by descriptive feature in SPSS software. Furthermore, through embedding the skewness and kurtosis coefficients in the descriptive analysis function, the normality of data distribution can be examined (Field, 2009).

Table 2 shows the descriptive analysis reported by the SPSS output.

The suggested range for both skewness and kurtosis coefficients is -2.00 to +2.00 . This range is recommended by Field (2009) to indicate normality of different data. As depicted in Table 2 and recommendation range by Field (2009), the data collected for this study for the whole variables was experienced a normal distribution. 
Table 2. Descriptive analysis

\begin{tabular}{|c|c|c|c|c|c|c|c|}
\hline & N & Min & Max & Mean & $\begin{array}{c}\text { Std. } \\
\text { Deviation }\end{array}$ & Skewness & Kurtosis \\
\hline IEM & 72 & 1.00 & 5.00 & 2.2837 & 0.90716 & 0.793 & 0.276 \\
\hline SPr & 72 & 1.00 & 5.00 & 2.0861 & 0.96112 & 0.931 & 0.269 \\
\hline SD & 72 & 1.00 & 5.00 & 2.2801 & 1.00928 & 0.770 & -0.186 \\
\hline SL & 72 & 1.00 & 5.00 & 2.3426 & 0.94110 & 0.797 & 0.248 \\
\hline SP & 72 & 1.00 & 5.00 & 2.4444 & 0.87076 & 0.549 & -0.088 \\
\hline EP & 72 & 1.00 & 5.00 & 2.7837 & 0.94882 & 0.032 & -0.561 \\
\hline Valid No. & 72 & & & & & & \\
\hline
\end{tabular}

\subsection{Data Quality}

Concerning the content and face validity, because the whole measurements were employed based on previous research (Green et al., 2012b; Zhu et al., 2008a) and confirmed and adopted by other scholars (Hsu et al., 2013; Green et al., 2012a), content and face validity were confirmed. On the other hand, construct validity is usually evaluated by factor analysis through adopting exploratory factor analysis (EFA) as tested in the following sections.

The reliability is another significant content for examining data quality. The reliability is using for evaluating consistency and repeatability of different research indicators. In various quantitative research, the Cronbach's value (alpha) was adopted for testing the reliability (Kaplan, 2004; Field, 2009). The minimum rate for Alpha value is 0.60 and the ideal range is maximum 0.70 . This range determines the high reliability in different variables (Hair et al., 2010; Field, 2009). To attain the recommended value of alpha, sometimes reducing the number of indicators sometimes is essential. By reduction of measurement items, the reliability of the construct can be improved. The primary results for Cronbach's Alpha value for different measurement items are mentioned in Table 3.

According to Table 3 alpha value for the IEM, SPr, SD, SL, SP, and EP is more than ideal value 0.70 that specify the high reliability of these measurement items. Subsequently, the general reliability for the whole measurements in this research was assessed as adequate level by an average of 0.913 .

\subsection{Factor Analysis}

In essence, factor loading represents the equating of measurement items and their equivalent factor. Exploratory factor analysis is adopted as a major statistical judgment for testing the significance of factors (Kaplan 2004). Concerning to extract the significant factors, Factor analysis employs principal component analysis (PCA) with Varimax rotation technique in SPSS software (Field, 2009). The

Table 3. Primary result for reliability indicator (Cronbach's Alpha)

\begin{tabular}{|c|c|}
\hline Variable & Cronbach's Alpha \\
\hline IEM & 0.912 \\
\hline SPr & 0.921 \\
\hline SD & 0.926 \\
\hline SL & 0.890 \\
\hline SP & 0.896 \\
\hline EP & 0.934 \\
\hline
\end{tabular}


variable by low factor loading will remove from the evaluation. This reduction can improve construct validity (Hair et al. 2010). Field (2009) argues that, PCA is represented by eigenvalues. Subsequently, Hair et al. (2010) suggest that factors by eigenvalues greater than 1 are considered satisfactory.

The Kaiser-Meyer-Olkin (KMO) is an index utilised to investigate the appropriateness of factor analysis technique in different research. The minimum recommended of KMO that is crucial for using factor analysis is 0.60 (Field, 2009; Luthra et al., 2014). To extract factors, the factor analysis rotation approach, particularly the Varimax rotation technique was utilised in this research. The Varimax method is defined as "maximising the dispersion of loading with factors and loads a smaller number of variables highly onto each factor resulting in more interpretable clusters of factors" (Field, 2009 , p.64). This rotation solution can give visual information regarding specifying items that should remove while other remaining items can sustain as one factor (Field, 2009). The following sections explains the factor analysis for different variables in this study.

\subsection{IEM, SSCM Practices, and EP}

Considering the whole measurement items with higher KMO value than the minimum recommended value 0.60 by Field (2009), the factor analysis is applicable for this study (see Table 4).

Table 4. KMO value for different measurement items

\begin{tabular}{|c|c|}
\hline Measurement Item & KMO \\
\hline IEM & 0.841 \\
\hline SPr & 0.880 \\
\hline SD & 0.846 \\
\hline SL & 0.696 \\
\hline SP & 0.861 \\
\hline EP & 0.919 \\
\hline
\end{tabular}

Table 5 shows eigenvalue for different measurement items that in the whole measurement items are greater than one. However, the factor analysis determines the two-factor solution for IEM, four different SSCM practices, and EP. These results indicate the measurement items are not performed as a unique factor.

Table 5. Eigenvalue for different measurement items

\begin{tabular}{|c|c|}
\hline Measurement Item & eigenvalues \\
\hline IEM & 4.647 \\
\hline SPr & 3.815 \\
\hline SD & 4.392 \\
\hline SL & 2.466 \\
\hline SP & 3.979 \\
\hline EP & 5.026 \\
\hline
\end{tabular}


As mentioned before, these issues can be eliminated by removing the number of measurement items to achieve the construct validity (Hair et al., 2010). Based on factor analysis results, some measures contain apparent inconsistency with other measurement items. The distance of these measurements from other measurements restricted them to perform as a unique factor. As mentioned before, Field (2009) proffers the measurements with this feature should exclude from other measurement items. Subsequently, for attaining the one-factor result, as shown in individual Varimax rotation plots, the IEM 1, IEM 2, SPr 5, SD 5, SD 6, SL 1, SP 1, SP 2, and EP 1 were removed. After repeating execution of the factor analysis regarding the different item measure, the factor analysis represented the one-factor performance. Table 6 represents the final results of Alpha values concerning reliability analysis in this study. This result was calculated after refining the measurements.

Table 6. Final result for reliability indicator (Cronbach's Alpha); Source: Researcher

\begin{tabular}{|c|c|}
\hline Variable & Cronbach's Alpha \\
\hline IEM & 0.924 \\
\hline SPr & 0.920 \\
\hline SD & 0.922 \\
\hline SL & 0.788 \\
\hline SP & 0.901 \\
\hline EP & 0.931 \\
\hline
\end{tabular}

\subsection{Multi-Collinearity (Collinearity)}

A significant risk for the structural models is multi-collinearity. The reason behind the fact that the multi-collinearity can impose a direct effect on different measure items. Considering these impacts, multi-collinearity can lead the regression weights toward inappropriate estimation (Hair et al., 2010).

The variance inflation factors (VIF) are a representative indicator for testing the multi-collinearity. This evaluation should calculate before providing the results of the hypothesis test. The VIF value according to Hair et al. (2010) should be lower than or equal to 10.0. In terms of the first model and investigation relationship between IEM and SSCM practices, the VIF values range is shown in Table 7. The VIF range is between 2.071 and 3.914, considerably lower than the recommended threshold of 10.0. These results were proved multi-collinearity cannot cause any problem for the first model in this research. Regarding the second model (the relationship between SSCM practices and EP), the VIF value for EP as dependent variable and SPr, SD, SL, and SP as independent variables are 1. This result is below the recommended threshold of 10.0.

Table 7. VIF value for model 1 (IEM-SSCM practices)

\begin{tabular}{|c|c|}
\hline Variable & VIF \\
\hline IEM and SPr & 2.071 \\
\hline IEM and SD & 3.914 \\
\hline IEM and SL & 2.983 \\
\hline IEM and SP & 2.995 \\
\hline
\end{tabular}


The correlations matrix as another test for collinearity is presented in Table 8 . As mentioned in Table 8, the whole of correlation coefficients for different variables was significant and positive at the 0.01 level. This significant correlation is obtained through adopting appropriate measurement scales, as well as establishing the (EFA) analysis. Furthermore, the correlation coefficient values (see Table 8) which is less than the maximum recommended value 0.80 is another reason for lack of the multi-collinearity threat in this study. These results were proved the multi-collinearity cannot be considered as a threat to this study.

Table 8. Correlation matrix; Source: Researcher

\begin{tabular}{|c|c|c|c|c|c|c|}
\hline & IEM & SPr & SD & SL & SP & EP \\
\hline IEM & 1 & & & & & \\
\hline SPr & $0.771^{* *}$ & 1 & & & & \\
\hline SD & $0.695^{* *}$ & $0.697^{* *}$ & 1 & & & \\
\hline SL & $0.645^{* *}$ & $0.537^{* *}$ & $0.782^{* *}$ & 1 & & \\
\hline SP & $0.630^{* *}$ & $0.639^{* *}$ & $0.770^{* *}$ & $0.744^{* *}$ & 1 & \\
\hline EP & $0.658^{* *}$ & $0.498^{* *}$ & $0.596^{* *}$ & $0.600^{* *}$ & $0.579^{* *}$ & 1 \\
\hline
\end{tabular}

${ }^{* *}$. Correlation is significant at the 0.01 level (2-tailed).

\subsection{Regression Analysis}

Hair et al. (2010) argue that the multiple regression analyses can be employed to indicate impacts of independent variables on a dependent variable. The regression coefficient ( $($ ), t-value, and R-squared are major indicators for examining different hypotheses in various studies (Hair et al., 2010). The regression coefficient (B) determines the rate of change for a dependent variable based on changes in independent variables (Hair et al., 2006, p.174). Concerning the first model of this study, (ß) value is represented the effect of IEM as an independent variable on SSCM practices as dependent variables. In terms of the second model, (ß) value is depicted the effect of SSCM practices as an independent variable on EP as a dependent variable. Meanwhile, commonly the t-value perceives as an indicator for representing the regression significance (Field, 2009). The recommended threshold of t-values is greater than 1.96 (Byrne, 1998). The R-squared (R2) is another statistical measurement item determines the distance of observed data from the fitted regression line (Hair et al., 2006; Field, 2009). Subsequently, with the higher R2 value (from 0 to 1 ), the higher explanatory power can achieve (Hair et al., 2006).

Table 9 shows the findings from multiple regression analyses of IEM-SSCM practices as the first model of this study. This model was significant $(\mathrm{F}=34.204 ; \mathrm{p}<0.001)$ with $\mathrm{R}^{2}=0.671$. Concerning sustainable purchasing, it was significantly related with IEM by $(\beta=0.561$, t-value $>1.96$ and $\mathrm{p}<$ $0.001)$. In terms of sustainable design and sustainable production, were not found any relationship with IEM by $(\beta=0.093$, t-value $<1.96$ and $\rho>0.05)$ and $(\beta=-0.003$, $\mathrm{t}$-value $<1.96$ and $\mathrm{p}>0.05)$, respectively. In addition, sustainable logistics was fairly significant related with IEM by $(\beta=0.273$, $\mathrm{t}$-value $>1.96$ and $\mathrm{p}<0.05)$.

To sum up, regarding the linkage between IEM and SSCM practices, SPr and SL with significant and positive coefficient value supported the hypotheses in this model. On the contrary, SP and SD did not support the hypotheses in this model. This verifies that Iranian manufacturing companies are still at an initial stage of SSCM practices (Soltani et al. 2015). In the preliminary stage, there is a lack of real data and results that can confirm positive outcomes of SSCM practices adoption on organisation performance. This lack of real data history may decrease the commitment and motivation level of 
International Journal of Strategic Engineering

Volume $3 \cdot$ Issue $2 \cdot$ July-December 2020

Table 9. Hypothesis tests results-model 1; Source: Researcher

\begin{tabular}{|c|c|c|c|c|}
\hline Independent variables & Standardised coefficient $(\boldsymbol{\beta})$ & t-value & $\mathbf{p}$ & Hypothesis tests results \\
\hline Sustainable Purchasing & $0.561^{* *}$ & 5.565 & $<0.01$ & H1a: Supported \\
\hline Sustainable Production & $-0.003^{\text {ns }}$ & -0.027 & $>0.05$ & H1b: Not Supported \\
\hline Sustainable Logistics & $0.273^{*}$ & 2.261 & $<0.05$ & H1c: Supported \\
\hline Sustainable Design & $0.093^{\text {ns }}$ & 0.672 & $>0.05$ & H1d: Not Supported \\
\hline
\end{tabular}

Notes: * significant at the 0.05 level; ** significant at the level 0.01 ; ns: not significant;

top and middle managers. As mentioned in the literature section, the support and commitment of different managerial level can affect expediting employee involvement and cultural shift in different organisations. In addition, taking advantages of the cross-functional team requires the full support of senior management (Carter et al., 1998). Furthermore, both practices that are supported in this model were external practices that need appropriate collaboration with suppliers and logistics providers. Therefore, these results refer to the fact that Iranian manufacturing companies still consider SSCM as an approach for assisting external practices and have more concentrated on them. It is seen that they also internally require achieving sufficient knowledge and capacity for successful SSCM implementation, particularly for internal SSCM practices, such as SP and SD (Vachon and Klassen, 2008).

Regarding model 2, Table 10 presents the results of the regression analysis of evaluating effects of SSCM practices on EP. According to Table 10, the whole of SSCM practices are significantly and positively related to EP. As a result, according to the proposed hypotheses in this research, the EP is positively affected by SSCM practices, particularly SPr, SP, SD, and SL. These results are in accordance with arguments of Green et al. (2012a) and Zhu and Sarkis (2007). They argue SSCM practices are developed to minimise adverse environmental impacts. Companies can improve their environmental performance by decreasing their negative environmental impacts.

Table 10. Hypothesis tests results-model 2

\begin{tabular}{|c|c|c|c|c|}
\hline Dependent variables & Standardised coefficient $(\boldsymbol{\beta})$ & t-value & p & $\begin{array}{c}\text { Hypothesis tests } \\
\text { results }\end{array}$ \\
\hline Sustainable Purchasing & $0.498^{* *}$ & 4.801 & $<0.01$ & H2a: Supported \\
\hline Sustainable Production & $0.579 * *$ & 5.949 & $<0.01$ & H2b: Supported \\
\hline Sustainable Logistics & $0.600^{* *}$ & 6.278 & $<0.01$ & H2c: Supported \\
\hline Sustainable Design & $0.596^{* *}$ & 6.206 & $<0.01$ & H2d: Supported \\
\hline
\end{tabular}

Notes: * significant at the 0.05 level; ** significant at the level 0.01 ; ns: not significant;

As shown in Table 10, based on $(\beta)$ value, Sustainable logistics has the highest impact and sustainable purchasing has the lowest impact on the environmental performance of manufacturing companies in Iran. Based on the concentration of SSCM practices on minimising the various logistics impacts including materials flows and pollution by transportation activities, this positive and strong causal relationship between sustainable logistics and environmental performance was expected (Lakshmimeera and Palanisamy, 2013).

Furthermore, Sabetghadam (2006) argues the transportation sector with $27.5 \%$ of CO2 emission has considerable negative impacts on environmental performance in Iran. Subsequently, according to sustainable development goals, decreasing the destructive effects of this sector is placed as priority for regulatory bodies, government, and manufacturing sectors in Iran. 
Concerning the relationship between $\mathrm{SPr}$ and EP, this research model by $\left(\mathrm{R}^{2}=0.379\right)$ can explain $37.9 \%$ of the variance. In addition, the explanatory power of other dependent variables such as SD, SL, and SP based on $\mathrm{R}^{2}$ value are $48.5 \%, 48.2 \%$, and $43.9 \%$ respectively.

In terms of sustainable purchasing, its significant and positive impact (see Table 10) on EP represents the fact its adoption provides the enhancement of environmentally friendly goods and services. It can also support organisations to minimise the different types of wastes and emissions (Hollos et al., 2012; Sarkis et al., 2010). However, since the standardized coefficient for this variable is lower than other variables, the more development, and improvement for this practice in Iranian manufacturing companies is required. The reason lies in the fact that the whole of the petrochemical and the steel industry in Iran purchase their raw materials from monopoly suppliers. In this light, negotiation about the environmental concerns with suppliers may lead these manufacturing sectors to lose the main suppliers and shortage of essential raw materials (Sabetghadam, 2006).

Concerning sustainable designing and sustainable production, the positive and significant relationship of these practices with EP was confirmed with the previous results and recent work by Green et al. (2012a), Zhu and Sarkis (2007), and Zhu et al., (2013).

According to Zhu et al., (2007), the main aim of sustainable logistics is minimising the environmental pollutants rate, thus it leads to positive impacts on improving EP. The findings in this research (see Table 10) also are other evidence to demonstrate the direct impacts of implementing SL on EP.

Figure 2 depicts the final research model according to the regression analysis results.

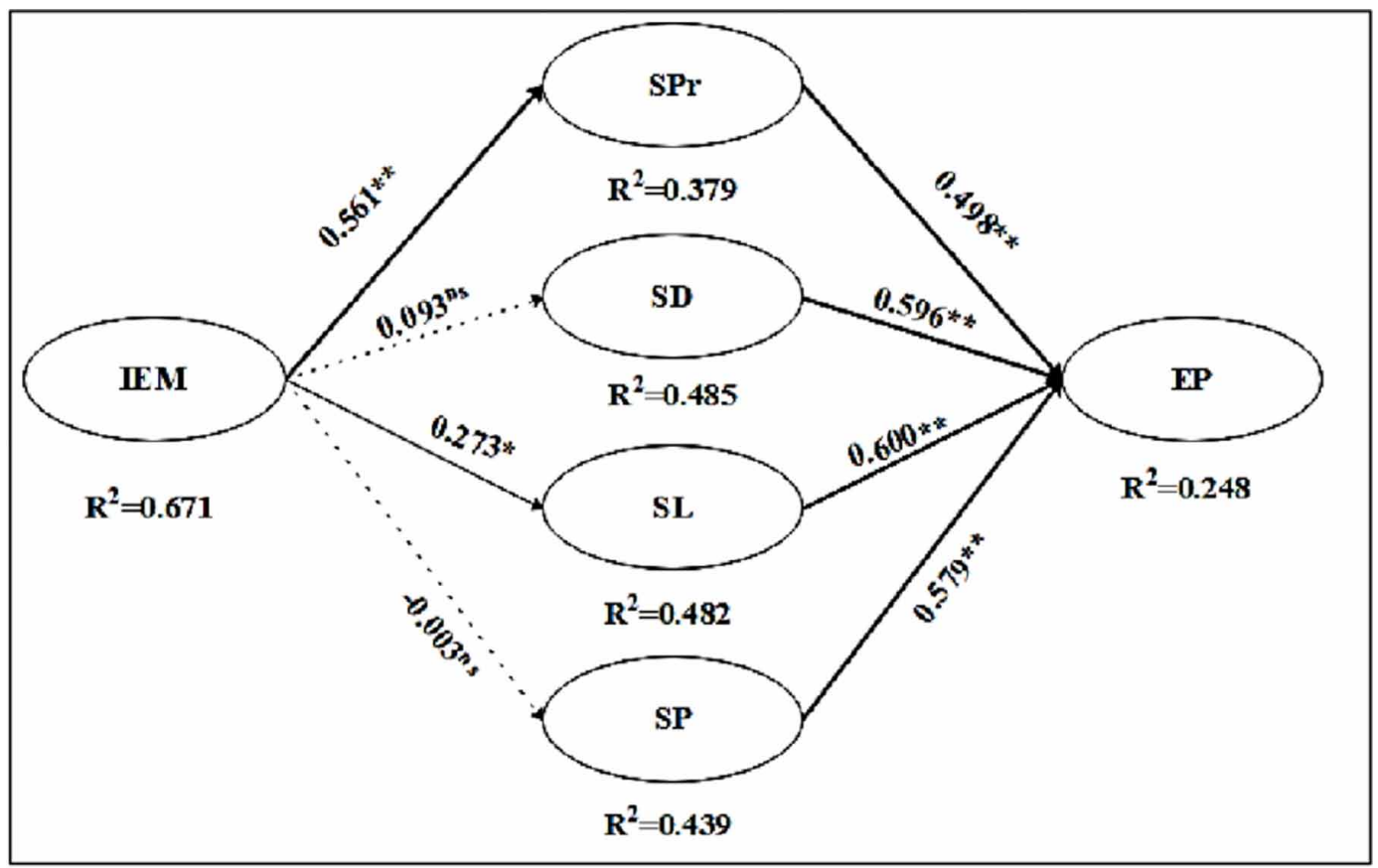

Notes: * significant at the 0.05 level; ** significant at the level 0.01 ; ns: not significant;

Solid bold arrow: causal effect that is positive and significant at level 0.01

Solid normal arrow: causal effect that is positive and significant at level 0.05

Dashed arrow: not significant and causal effect 


\section{CONCLUSION}

Through the past two decades, SSCM is seen as a favourite attitude among manufacturing companies. The reason is that by adopting this approach they can achieve economic advantages as well as mitigate their environmental risk and damage (Pagell and $\mathrm{Wu}, 2009$ ). However, the intensive complexities concerning organising and implementing this approach are inevitable (Walker et al., 2008). Furthermore, recently different debates were raised regarding doubts and uncertainties about the role and place of SSCM adoption in improving environmental performance (Shi et al., 2012). Accordingly, this research conceptualised a model and evaluated the theoretical relationship among the main research clusters of IEM-SSCM practices-EP based on this model.

The particular focus of this research was Iranian manufacturing companies as one of the key polluting sectors in this emerging country.

The research objectives guided this research to answer the main research question. Regarding the first objective, according to literature as well as most SSCM practices that were placed in Iranian government priority, four main SSCM practices were selected (Esfahbodi et al. 2016; Soltani et al., 2015; Govidan et al, 2014a; Geng et al., 2013). These SSCM practices include sustainable purchasing, sustainable production, sustainable design, sustainable logistics.

In terms of assessing the relationship between IEM and SSCM practices, a conceptual model was developed. To assess the research model, a quantitative approach was employed. In this approach, a survey questionnaire was utilised for collecting data. Subsequently, 72 different questionnaires from the top and middle managers of six individual manufacturers in Iran were collected. These companies were from different industries, such as the petrochemical industry, metal and steel industry, as well as the agriculture sector. Their managers had experience and knowledge in the areas related to SSCM and include plant managers, transportation managers, purchasing managers, production managers, engineering managers, planning managers, HSE managers. Lastly, concerning realizing the causal relationship in the research models the multiple regressions analysis was applied. This technique supports this study to test the proposed hypotheses.

Due to assessing the proposed hypotheses in the first model, the following results were obtained: Concerning sustainable purchasing, it was significantly related with IEM by $(\beta=0.561$, $t$-value $>1.96$ and $\mathrm{p}<0.001)$. Sustainable design and sustainable production were not found to have any relationship with IEM by $(\beta=0.093$, $t$-value $<1.96$ and $\mathrm{p}>0.05)$ and $(\beta=-0.003$, $\mathrm{t}$-value $<1.96$ and $\mathrm{p}>0.05)$, respectively. In addition, sustainable logistics was significant related with IEM by $(\beta=$ 0.273 , t-value $>1.96$ and $\mathrm{p}<0.05$ ). Consequently, the hypotheses regarding the positive relationship between IEM and two different practices of SPr and SL were supported in this research. On the other hand, the hypotheses about the positive linkage between IEM and two different practices of SP, SD were not supported in this study.

In order to obtain the third objective, after developing a conceptual model and testing the proposed hypotheses, the following findings were achieved:

According to proposed hypotheses in this research, EP was positively affected by SSCM practices, particularly SPr, SP, SD, and SL. These results are in accordance with the arguments of Green et al. (2012a), Zhu and Sarkis (2007).

Most of the hypotheses in the research model were supported through statistical significance level. Consequently, it is asserted that the research model is appropriate for describing the theoretical linkage among the essential research clusters. Besides, based on the mentioned features of the research model, it can be considered as an efficient model for answering the research question in this study. Therefore, in line with the last objective, after developing the initial conceptual model and testing different hypotheses, the final conceptual model (see Figure 2) was achieved. 
International Journal of Strategic Engineering Volume $3 \cdot$ Issue $2 \cdot$ July-December 2020

This study can help practitioners in various industries by assessing the impacts of the adoption of SSCM practices on EP as well as impacts of IEM on SSCM practices. Furthermore, this research can provide information for managers to recognise those parts of SSCM that require more improvements or that they need to consider as their priorities. 
International Journal of Strategic Engineering

Volume $3 \cdot$ Issue $2 \cdot$ July-December 2020

\section{REFERENCES}

Bratic, D. (2011). Achieving a Competitive Advantage by SCM. IBIMA Business Review. Retrieved from https:// ibimapublishing.com/articles/IBIMABR/2011/957583/957583.pdf

Bryman, A. (2001). Social Research Methods. UK: OXFORD University Press.

Bryman, A., \& Bell, E. (2015). Business Research Methods. UK: Oxford University Press.

Byrne, B. M. (1998). Structural Equation Modelling with LISREL, PRELIS, and SIMPLIS. Mahwah, NJ: Lawrence Erlbaum Associates.

Carson, D., Gilmore, A., Perry, C., \& Gronhaug, K. (2001). Qualitative Marketing Research. London: Sage. doi:10.4135/9781849209625

Carter, C. (2014). The transformation of Scottish fisheries: Sustainable interdependence from "net to plate. Marine Policy, 44, 131-138. doi:10.1016/j.marpol.2013.08.014

Carter, C. R., \& Carter, J. R. (1998). Inter organizational determinants of environmental purchasing: Initial evidence from the consumer products industry. Decision Sciences, 29(3), 28-38. doi:10.1111/j.1540-5915.1998. tb01358.x

Carter, C. R., \& Ellram, L. M. (2003). Thirty-five years of the Journal of Supply Chain Management: Where have we been and where are we going? The Journal of Supply Chain Management, 39(1), 38-50. Retrieved from https:// www.questia.com/library/journal/1G1-101679406/thirty-five-years-of-the-journal-of-supply-chain-management

Carter, C. R., \& Easton, P. L. (2011). 'Sustainable supply chain management: Evolution and future directions. International Journal of Physical Distribution \& Logistics Management, 41(1), 46-62. doi:10.1108/09600031111101420

Carter, C. R., \& Jennings, M. M. (2004). The role of purchasing in corporate social responsibility: A structural equation analysis. Journal of Business Logistics, 25(1), 145-186. doi:10.1002/j.2158-1592.2004.tb00173.x

Carter, C. R., \& Rogers, D. S. (2008). A framework of sustainable supply chain management: Moving toward new theory. International Journal of Physical Distribution \& Logistics Management, 38(5), 360-387. doi:10.1108/09600030810882816

Cheremisinoff, N. P., Rosenfeld, P. E., \& Davletshin, A. R. (2008). Responsible care a new strategy for pollution prevention and waste reduction through environmental management. Houston, TX: Gulf Publishing Company.

Chicksand, D., Watson, G., Walker, H., Radnor, Z., \& Johnston, R. (2012). Theoretical perspectives in purchasing and supply chain management: An analysis of the literature. Supply Chain Management, 17(4), 454-472. doi:10.1108/13598541211246611

Dyllick, T., \& Hockerts, K. (2002). Beyond the business case for corporate sustainability. Business Strategy and the Environment, 11(2), 130-141. doi:10.1002/bse.323

Elkington, J. (2004). Enter the triple bottom line. In A. Henriques \& J. Richardson (Ed.), The Triple Bottom Line: Does It All Add up? London: Earthscan.

Esfahbodi, A., Zhang, Y., \& Watson, G. (2016). Sustainable supply chain management in emerging economies: Trade-offs between environmental and cost performance. International Journal of Production Economics, 181, 350-366. doi:10.1016/j.ijpe.2016.02.013

Feizpour, M. A., \& Mehrjardi, A. S. (2014). Comparative advantages and sustainable development in Iranian manufacturing industries. Iranian Economic Review, 18(1), 33-52. Retrieved from https://ier.ut.ac.ir/ article_53286.html

Field, A. (2009). Discovering Statistics Using SPSS. Thousand Oaks, CA: SAGE Publications Ltd.

Forza, C. (2002). Survey research in operations management: A process-based perspective. International Journal of Operations \& Production Management, 22(2), 152-194. doi:10.1108/01443570210414310 
Giunipero, L. C., Hooker, R. E., Joseph-Matthews, S., Yoon, T. E., \& Brudvig, S. (2008). A decade of SCM literature: Past, present and future implication. The Journal of Supply Chain Management, 44(4), 66-86. doi:10.1111/j.1745-493X.2008.00073.x

Govindan, K., Kaliyan, M., Kannan, D., \& Haq, A. N. (2014a). Barriers analysis for green supply chain management implementation in Indian industries using analytic hierarchy process. Journal of Cleaner Production, 147, 555-568. doi:10.1016/j.jclepro.2019.117617

Golicic, S., \& Davis, D. (2012). Implementing mixed methods research in supply chain management. International Journal of Physical Distribution \& Logistics Management, 42(8/9), 726-741. doi:10.1108/09600031211269721

Green, K. Jr, Zelbst, P., Meacham, J., \& Bhadauria, V. (2012). Green supply chain management practices: Impact on performance. Supply Chain Management, 17(3), 290-305. doi:10.1108/13598541211227126

Handfield, R., Sroufe, R., \& Walton, S. (2005). Integrating environmental management and supply chain strategies. Business Strategy and the Environment, 14(1), 1-19. doi:10.1002/bse.422

Hair, J. F., Black, W. C., Babin, B. J., Anderson, R. E., \& Tatham, R. L. (2006). Multivariate Data Analysis. Upper Saddle River, NJ: Pearson/Prentice-Hall.

Hair, J. F., Anderson, R. E., Tatham, R. L., \& Black, W. C. (2010). Multivariate Data Analysis. New Jersey: Prentice-Hall.

Hall, J., \& Matos, S. (2010). Incorporating impoverished communities in sustainable supply chains. International Journal of Physical Distribution \& Logistics Management, 40(1/2), 124-147. doi:10.1108/09600031011020368

Hollos, D., Blome, C., \& Foerstl, K. (2012). Does sustainable supplier cooperation affect performance? Examining implications for the triple bottom line. International Journal of Production Research, 50(11), 2968-2986. doi $: 10.1080 / 00207543.2011 .582184$

Hu, A. H., \& Hsu, C. W. (2010). Critical factors for implementing green supply chain management practice: An empirical study of electrical and electronics industries in Taiwan'. Management Research Review, 33(6), 586-608. doi:10.1108/01409171011050208

Hsu, C. C., Tan, K. C., Zailani, S. H. M., \& Jayaraman, V. (2013). Supply chain drivers that foster the development of green initiatives in an emerging economy. International Journal of Operations \& Production Management, 33(6), 656-688. doi:10.1108/IJOPM-10-2011-0401

Inman, A., Sale, S., Green, K. W. Jr, \& Whitten, D. (2011). Agile manufacturing: Relation to JIT, operational performance and firm performance. Journal of Operations Management, 29(4), 343-355. doi:10.1016/j. jom.2010.06.001

Jain, R. (2015). Environmental impact of mining and mineral processing: management, monitoring, and auditing strategies. Butterworth-Heinemann.

Jayaram, J., \& Avittathur, B. (2015). Green supply chains: A perspective from an emerging economy. International Journal of Production Economics, 164, 234-244. doi:10.1016/j.ijpe.2014.12.003

Kaplan, D. (2000). Structural Equation Modelling Foundations and Extensions. Thousand Oaks, CA: SAGE Publications.

Kaplan, D. (2004). The SAGE Handbook of Quantitative Methodology for the Social Sciences. Thousand Oaks, CA: SAGE Publications. doi:10.4135/9781412986311

Kline, R. B. (2011). Principles and Practice of Structural Equation Modelling, Methodology in the Social Sciences. London: The Guildford Press.

Kuik, S., Amer, Y., \& Nagalingam, S. (2011). Sustainable supply chain for collaborative manufacturing. Journal of Manufacturing Technology Management, 22(8), 984-1001. doi:10.1108/17410381111177449

Kumar, A., Jain, V., \& Kumar, S. (2014a). A comprehensive environment friendly approach for supplier selection. Omega, 42(1), 109-123. doi:10.1016/j.omega.2013.04.003 
International Journal of Strategic Engineering

Volume $3 \cdot$ Issue $2 \cdot$ July-December 2020

Lakshmimeera, B. L., \& Palanisamy, C. (2013). A Conceptual Framework on Green Supply Chain Management Practices. Industrial Engineering Letters, 3(10), 42-52. https://www.iiste.org/Journals/index.php/IEL/article/ view/8009

Layder, D. (1988). The Relation of Theory and Method: Causal Relatedness. The Sociological Review, 36(3), 441-463. doi:10.1111/j.1467-954X.1988.tb02923.x

Lee, S. M., Kim, S. T., \& Choi, D. (2012). Green supply chain management and organizational Performance. Industrial Management \& Data Systems, 112(8), 1148-1180. doi:10.1108/02635571211264609

Lozano, R. (2008). Developing collaborative and sustainable organisations. Journal of Cleaner Production, 16(4), 499-509. doi:10.1016/j.jclepro.2007.01.002

Lozano, R., Carpenter, A., \& Huisingh, D. (2015). A review of 'theories of the firm' and their contributions to corporate sustainability. Journal of Cleaner Production, 106, 430-442. doi:10.1016/j.jclepro.2014.05.007

Luthra, S., Garg, D., \& Haleem, A. (2014). Critical success factors of green supply chain management for achieving sustainability in Indian automobile industry. Production Planning \& Control: The Management of Operations, 26(5), 339-362. https://www.tandfonline.com/doi/full/10.1080/09537287.2014.904532

Mentzer, J. T., \& Kahn, K. B. (1995). A framework of logistics research. Journal of Business Logistics, 16(1), $231-250$.

Moore, D., \& Babu, A. S. (2008). Perspectives, practices, and future of supply chain flexibility. International Journal of Business Excellence, 1(3), 302-336. doi:10.1504/IJBEX.2008.017885

Mudgal, R. K., Shankar, R., Talib, P., \& Raj, T. (2009). Greening the supply chain practices: An Indian perspective of enablers' relationships. International Journal of Advanced Operations Management, 1(2), 151-176. doi:10.1504/IJAOM.2009.030671

Nahm, A. Y., \& Vonderembse, M. A. (2002). Theory Development: An industrial/post- industrial perspective on manufacturing. International Journal of Production Research, 40(9), 2067-2095. doi:10.1080/00207540210128233

Pagell, M., \& Wu, Z. (2009). Building a more complete theory of sustainable supply chain management using case studies of 10 exemplars. The Journal of Supply Chain Management, 45(2), 37-56. doi:10.1111/j.1745493X.2009.03162.x

Sabetghadam, M. (2006). Energy and Sustainable Development in Iran. United Nations Sustainable Development. Retrieved from https://sustainabledevelopment.un.org/content/documents/854Iran-EN.pdf

Sarkis, J. (2006). Greening the Supply Chain. London: Springer. doi:10.1007/1-84628-299-3

Sarkis, J., Gonzalez-Torre, P., \& Adenso-Diaz, B. (2010). Stakeholder Pressure and the Adoption of Environmental Practices: The Mediating Effect of Training. Journal of Operations Management, 28(2), 163-176. doi:10.1016/j. jom.2009.10.001

Thornhill, A., Saunders, M., \& Lewis, P. (2009). Research methods for business students. London: Prentice Hall.

Seuring, S., \& Müller, M. (2008). From a literature review to a conceptual framework for sustainable supply chain management. Journal of Cleaner Production, 16(15), 1699-1710. doi:10.1016/j.jclepro.2008.04.020

Seuring, S., \& Gold, S. (2013). Sustainability management beyond corporate boundaries: From stakeholders to performance. Journal of Cleaner Production, 56, 1-6. doi:10.1016/j.jclepro.2012.11.033

Shi, V. G., Koh, S. C. L., Baldwin, J., \& Cucchiella, F. (2012). Natural resource based green supply chain management. Supply Chain Management, 17(1), 54-67. doi:10.1108/13598541211212203

Shahmirzadi, H. E. (2017). Selecting an Appropriate Strategy to Increase Petrochemical Product Sales (Case Study: Iranian Petrochemical Industry). Business and Management Studies, 3(1), 42. doi:10.11114/bms.v3i1.2247

Skinner, W. (1985). The Taming of lions: How manufacturing leadership evolved 1780-1984. In K. B. Clark, R. Hayes, \& C. Lorenz (Eds.), The Uneasy Alliance: Managing the Productivity-Technology Dilemma (pp. 63-114). Boston: Harvard School Press.

Soltani, E., Syed, J., Liao, Y.-Y., \& Iqbal, A. (2015). Managerial Mindsets Toward Corporate Social Responsibility: The Case of Auto Industry in Iran. Journal of Business Ethics, 129(4), 795-810. doi:10.1007/s10551-014-2137-4 
Srivastava, S. M. (2007). Green supply-chain management: A state-of-the-art literature Review. International Journal of Management Reviews, 9(1), 53-80. doi:10.1111/j.1468-2370.2007.00202.x

Tan, K., Shi, L., Tseng, M., \& Chiu, A. (2014). Managing the indirect effects of environmental regulation and performance measurement. Industrial Engineering \& Management Systems, 13(2), 148-153. doi:10.7232/ iems.2014.13.2.148

Teuteberg, F., \& Wittstruck, D. (2010). A Systematic Review of Sustainable Supply Chain Management Research. In MKWI 2010 - Betriebliches Umwelt- und Nachhaltigkeitsmanagement. Academic Press. Retrieved from https://www.researchgate.net/publication/277009487

Tu, Q., Vonderembse, M., \& Ragu-Nathan, T. S. (2001). The impact of time-based manufacturing practices on mass customization and value to customer. Journal of Operations Management, 19(2), 201-217. doi:10.1016/ S0272-6963(00)00056-5

Vachon, S. (2007). Green supply chain practices and the selection of environmental Technologies. International Journal of Production Research, 45(18-19), 4357-4379. doi:10.1080/00207540701440303

Vezzoli, C., Ceschin, F., Diehl, J. C., \& Kohtala, C. (2012). Why have 'Sustainable Product- Service Systems' not been widely implemented? Meeting new design challenges to achieve societal sustainability. Journal of Cleaner Production, 35, 288-290. doi:10.1016/j.jclepro.2012.05.050

Vachon, S., \& Klassen, R. D. (2008). Environmental management and manufacturing performance: The role of collaboration in the supply chain. International Journal of Production Economics, 111(2), 299-315. doi:10.1016/j. ijpe.2006.11.030

Vonderembse, M. A., Ragunathan, T. S., \& Rao, S. S. (1997). A post-industrial paradigm: To integrate and automate manufacturing. International Journal of Production Research, 35(9), 2579-2599. doi:10.1080/002075497194679

Walker, H., Di Sisto, L., \& McBain, D. (2008). Drivers and barriers to environmental supply chain management practices: Lessons from the public and private sectors. Journal of Purchasing and Supply Management, 14(1), 69-85. doi:10.1016/j.pursup.2008.01.007

World Economic Forum. (2018). The Inclusive Development Index 2018. Retrieved from http://www3.weforum. org/docs/WEF_Forum_IncGrwth_2018.pdf

Zhu, Q., \& Sarkis, J. (2004). Relationships between operational practices and performance among early adopters of green supply chain management practices in Chinese manufacturing enterprises. Journal of Operations Management, 22(3), 265-289. doi:10.1016/j.jom.2004.01.005

Zhu, O., Sarkis, J., \& Geng, Y. (2005). Green supply chain management in china: Pressures, practices and performance. International Journal of Operations \& Production Management, 25(5), 449-468. doi: $10.1108 / 01443570510593148$

Zhu, Q., \& Sarkis, J. (2007). The moderating effects of institutional pressures on emergent green supply chain practices and performance. Journal International Journal of Production Research, 45(18-19), 4333-4355. doi:10.1080/00207540701440345

Zhu, Q., Sarkis, J., \& Lai, K. (2008a). Confirmation of a measurement model for green supply chain management practices implementation. International Journal of Production Economics, 111(2), 261-273. doi:10.1016/j. ijpe.2006.11.029

Zhu, Q., Sarkis, J., Lai, K., \& Geng, Y. (2008c). The role of organizational size in the adoption of green supply chain management practices in China. Corporate Social Responsibility and Environmental Management, 15(6), 322-337. doi:10.1002/csr.173

Zhu, Q., Hashimoto, S., Fujita, T., \& Geng, Y. (2010). Green supply chain management in leading manufacturers: Case studies in Japanese large companies. Management Research Review, 33(4), 380-392. doi:10.1108/01409171011030471

Zhu, Q., Sarkis, J., \& Lai, K. H. (2013). Institutional-based antecedents and performance outcomes of internal and external green supply chain management practices. Journal of Purchasing and Supply Management, 19(2), 106-117. doi:10.1016/j.pursup.2012.12.001 
International Journal of Strategic Engineering

Volume 3 • Issue 2 • July-December 2020

Zsidisin, G. A., \& Siferd, S. P. (2001). Environmental purchasing: A framework for theory development. European Journal of Purchasing \& Supply Management, 7(1), 61-73. doi:10.1016/S0969-7012(00)00007-1

Deneise Dadd is a Lecturer of Business and Management at Coventry University (CU), UK. At CU, she has been a course director of both undergraduate and postgraduate courses, supervises dissertation students at these levels, as well as leads modules for subjects including change management, leadership, and strategy. Deneise researches issues around performance (measurement, management and improvement) and sustainability in the supply chain (particularly clothing). Prior to joining academia, her career included roles as a management consultant, researcher and marketer. Deneise holds a PhD from the Open University, a MSc (Dist.) in Service Management from the University of Buckingham and a BSc (Hons) in Economics and Management Studies from the University of the West Indies. 